\title{
Localization and immunohistochemical detection of swine influenza $A$ virus subtype H1N1 antigen in formalin-fixed, paraffin-embedded lung tissues from naturally infected pigs
}

\author{
Moshood O. Olaniyi ${ }^{1 *}$ D, Adeniyi A. Adebiyi ${ }^{1}$, Olusola L. Ajayi ${ }^{1}$, Olugbenga O. Alaka ${ }^{2}$ and Stephen O. Akpavie ${ }^{2}$
}

\begin{abstract}
Background: Swine influenza A viruses (SIV) infection is among the leading causes of respiratory diseases in a number of animal species and human, and has been reported to cause substantial losses to pig industry. Previous reports of serological, molecular, and surveillance studies in commercial piggeries in Nigeria indicated the presence of SIV subtypes H1N1 and H3N2 in infected pigs; hitherto, there exists lack of studies on the pulmonary pathology and pathogenicity of SIV in Nigeria. This study investigates the presence of SIV subtype H1N1 antigen in the formalin-fixed paraffin-embedded lung sections obtained from apparently healthy pigs slaughtered at abattoirs located in Lagos, Ogun, and Oyo States, Southwest Nigeria using a streptavidin-biotin (ABC) immunoperoxidase (IP) staining. Two hundred four lungs consisting of 144 grossly pneumonic lungs and 60 apparently normal lungs were randomly collected, fixed in 10\% neutral-buffered formalin, embedded in paraffin wax, and processed for histopathological examination and immunohistochemistry.

Results: The main gross lesions were marked pulmonary edema and mild bilateral consolidation of cranial lobes. Histopathology revealed suppurative bronchitis, and bronchiolitis with or without concurrent widespread degeneration and necrosis of epithelial cells (52.08\%) and thickening of alveolar septa due to cellular infiltration consisting predominantly of neutrophils and mononuclear cells (macrophages and plasma cells) (39.58\%). The lumina of most airways contained exudate consisting of neutrophils, desquamated epithelia cells, and necrotic debris. SIV antigen was immunohistochemically detected in 7/204 (3.43\%) samples using SIV-specific (H1N1) monoclonal antibody. Positive cells exhibited a typical dark-brown reaction in the infected cells. A strong positive immunohistochemical staining was detected mainly in the alveolar macrophages and bronchial submucosal glandular epithelial cells while less intense staining was observed in the bronchiolar epithelial cells.

Conclusions: The present study describes the distribution and localization of SIV subtype H1N1 antigens in the lung tissues of the infected pigs and provides public awareness on the presence of the virus in pig population in Nigeria and the risk factors associated with the infection. Therefore, people working in pig farms should maintain high level of biosafety and personal hygiene. This is the first report of immunohistochemical detection of SIV subtype H1N1 antigen in naturally infected pigs in Nigeria and may indicate rapid dissemination of the virus in susceptible pigs in the study area. A further molecular epidemiological study to investigate other SIV subtypes circulating in Nigerian pig population is warranted.
\end{abstract}

Keywords: Histopathology, Immunoperoxidase staining, Pneumonia, Swine influenza A virus (H1N1) antigen, Pigs, Nigeria

\footnotetext{
* Correspondence: olaniyimo@funaab.edu.ng

'Department of Veterinary Pathology, College of Veterinary Medicine, Federal

University of Agriculture, Abeokuta, Nigeria

Full list of author information is available at the end of the article
} 


\section{Background}

The pig husbandry contributes significantly to the protein supply in the food chain, and serves as a source of livelihood for many households in Nigeria [1, 8]. However, the industry is mitigated by infectious diseases such as the menace of African swine fever that ravaged pig farms in some parts of Nigeria in recent past [11, 47, 53, $56]$ as well as respiratory diseases $[9,27,49,58]$

Respiratory diseases have been reported to be a serious constrain to intensive swine production and productivity world-wide $[9,30,41,60,61]$, and are arguably the most important health concerns to swine producers $[15,30]$ because the presence of respiratory disease in pigs is commonly associated with high production losses [52, 61, 62]. Swine influenza A viruses (SIV) is a common and economically important cause of respiratory disease in pigs $[26,50]$, and reported to result in huge economic losses [35, 41]. SIV infection has been recognized as a respiratory disease in swine since its first appearance concurrent with the 1918 "Spanish flu" human pandemic [35, 54]. The virus is enzootic in most of the pig-producing countries $[16,66]$ and known to infect human beings who are in close contact with sick pigs [6, 28, 43, 51]. Zoonotic infections of humans with swine influenza A viruses have been diagnosed and confirmed by isolation of the virus from both pigs and pig industry workers in many countries $[2,6,7,26,28,50]$. SIV is a member of family Orthomyxoviridae, containing a genome of single-stranded RNA segment [14-16, 51]. All influenza viruses of significance in swine are of type A but the most common subtypes currently circulating in swine are H1N1, H1N2, and H3N2 [13, 17, 20, 21, 35, 43, 50]. H3N2 subtype was reported to be the most dominant under the field conditions $[20,68]$, while H1N2 was reported to cause large-scale outbreaks of respiratory diseases in swine population in different parts of the world including Japan, Republic of Korea, and the United Kingdom [17, 33, 38]. Swine influenza viruses have been detected among swine populations in different parts of the world, including North America [40, 45], Europe [64, 66], South America [57], Australia/Oceania [24, 32], Asia [31], West and Central Africa [4, 25, 59], and Nigeria in particular [3-5, 7, 22]. In recent time, Njabo et al. [46] and Meseko et al. [44] also reported N1H1 in Cameroon and Nigeria, respectively. In addition, Adeola et al. [5] had earlier reported human H1 and $\mathrm{H} 3$ strains of influenza A virues in swine population in Ibadan, Nigeria. The transmission of the infection has been reported to occur mainly by oral route from influenzainfected pigs [34, 18]; lungworms may also transmit the virus of swine influenza [43]. Following infection, SIV attaches and replicates within epithelial cells of the respiratory tracts resulting in cell death $[35,38]$. The most consistent gross lesion of SIV infection is mild to moderate lobular, multifocal to coalescing distribution of consolidation which is most frequently observed in the cranial, middle, and accessory lobes and often demarcated from the normal tissue $[18,57,64]$. The hallmark microscopic lesions are necrotizing bronchitis and bronchiolitis with attenuation of bronchiolar lumen, atelectasis, and peribronchiolar, perivascular, and interstitial infiltration of lymphocytes and plasma cells [18, 35, 37, 38, 64] and intraluminal cellular exudate and necrotic debris [64]. In situ hybridization and immunohistochemistry results had previously reported that SIV infects alveolar macrophages where immune-signals were detected $[35,37,42,63]$. Although molecular studies and serological evidence of influenza A viruses in commercial piggeries in Nigeria has been previously reported $[3-5,7,44,48]$, the pulmonary pathology and pathogenicity of H1N1 subtype have not been studied. This study, therefore, describes the pulmonary pathological changes and pathogenesis following natural infection with swine influenza A virus subtype H1N1and studies the distribution and localization of influenza H1N1 virus antigen in the lung from naturally infected pigs in southwest Nigeria using immunohistochemistry.

\section{Methods}

\subsection{Study animals and sample collection}

The pigs were obtained from different farms in southwest Nigeria including Lagos, Ogun, Osun, and Oyo states and slaughtered in three major abattoirs located in Abeokuta, Ibadan, and Oko-Oba, Lagos. Lung samples of slaughterage pigs were randomly collected from these abattoirs as well as from carcasses submitted for post-mortem examination. A total of 204 lung samples consisting of 144 pneumonic lungs (case group) and 60 apparently normal lungs (control group) were randomly collected between February 2014 and September 2015 on 12 occasions, 8 weeks apart. Lung samples were immediately fixed in $10 \%$ neutral-buffered formalin, left to fix for at least $48 \mathrm{~h}$ and later processed for routine histopathology [12] and immunohistochemistry as described by Ceribasi et al. [19].

\subsection{Histopathological technique}

The 204 formalin-fixed lung tissues were prepared routinely and stained with hematoxylin and eosin (H\&E) for light microscopic examination.

\subsection{Immunohistochemistry protocol}

Immunohistochemical (IHC) test was used to detect SIV-specific antigens. One hundred four selected formalin-fixed, paraffin-embedded lung tissues were sectioned at 3-5 $\mu \mathrm{m}$ and processed for immunohistochemical staining. Paraffin-embedded tissue sections were deparaffinized in xylene, rehydrated through graded alcohol, and air dried. Deparaffinized tissue sections were pen-circled using PAP marker (Vector Lab., USA) and placed in antigen retrieval solution (Citra, BioGenex, 
CA, USA) using a plastic stander and kept in a microwave for $20 \mathrm{~min}$.

Slides were laid on the humid chamber, flooded with $3 \% \mathrm{H}_{2} \mathrm{O}_{2}$ (Fisher scientific ${ }^{\circ}$, UK), and incubated at room temperature for 15 min (two times) to quench endogenous peroxidase activity. After washing three times (5 min each) in phosphate-buffer saline (PBS, pH 7.4, 0.01 M) containing $0.1 \%$ Tween 20 , sections were treated with power block, IX blocking antibody (Universal Blocking Reagent, BioGenex, CA, USA) for 20 min to saturate nonspecific protein-binding sites.

After draining the excess blocking serum, sections were incubated with anti-influenza A virus (H1N1) monoclonal antibody (East Coast Bio. Inc., North Berwick, ME, USA) diluted to $1: 1000$ in PBS (pH 7.4, 0.01M) containing $0.1 \%$ Tween 20, and kept in a humidified chamber at $4{ }^{\circ} \mathrm{C}$ overnight. Dilutions tested were 1:500, 1:1000, and 1:2000. The 1:1000 dilution was the optimum, because, at this dilution, H1N1 antigen could be clearly detected with minimal background staining. After washing with PBS three times, sections were treated with biotinylated anti-mouse IgG made in goat secondary antibody (Vector Lab. Inc., CA, USA), applied at 1:250 dilution for $1 \mathrm{~h}$ at room temperature in a humidified chamber.

Sections were washed three times and further treated with a labeled peroxidase-conjugated streptavidin-biotin complex (Vectastain, Elite ABC, Vector Lab. Inc., CA, USA) for $1 \mathrm{~h}$. Preparation was carried out $30 \mathrm{~min}$ before use by diluting one drop of $\mathrm{A}+$ one drop of $\mathrm{B}$ in $2.5 \mathrm{ml}$ PBS. After another PBS bath (three times), sections were incubated with freshly prepared 3,3 diaminobenzidine tetrahydrochloride (DAB) (Vector Lab. Inc., CA, USA). The reaction was stopped after colour change (normally $5 \mathrm{~min}$ ). Finally, sections were washed in running tap water, counterstained with Gill hematoxylin (Vector Lab. Inc., CA, USA), dehydrated, and covered with VWR micro cover glass (VWR ${ }^{\circ}$, USA). Separate control slides of known SIV-positive lung tissue sections as well as known SIV-negative tissue sections prepared along with the test slides were used as positive and negative controls respectively, for each IHC run.

\section{Results}

\subsection{Gross pathology}

Gross lesions were observed in cranial lobes of all the pneumonic lungs. The acute lesion was characterized by pulmonary edema, hyperemia, and frothy exudate in the airways. There was a mild lobular multifocal consolidation of the cranial lobes of the infected lungs (Fig. 1), which was evidenced by sharp delineation between the affected and apparently normal tissues. A tentative diagnosis of acute bronchopneumonia was made based on these gross lesions. Lesions were generally mild because they were obtained from apparently healthy pigs

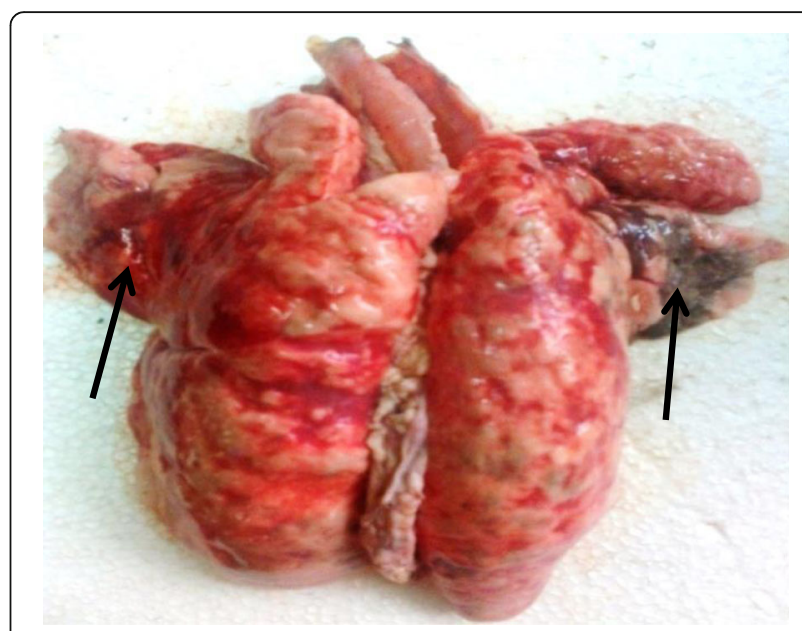

Fig. 1 Photograph of the lung showing marked pulmonary oedema and mild bilateral consolidation of cranial lobes (arrowed)

\subsection{Histopathological findings}

Microscopic lesions were found in all the lungs with gross pneumonic lesions. Based on the histopathological examination, the lesions were classified into acute $(124 / 144$, $86.1 \%)$, subacute $(17 / 144,11.8 \%)$, or chronic $(3 / 144,2.1 \%)$ cases of broncho-interstitial pneumonia. All acute cases $(n$ = 114) were mainly suppurative bronchopneumonia (BP). A few lungs showed bronchiolitis with presence of catarrhal exudate in the bronchiolar lumen (Fig. 2a). Bronchitis and bronchiolitis were mainly suppurative with concurrent epithelial hyperplasia and presence of intraluminal cellular exudate and necrotic debris (Fig. 2b) with attenuation of bronchiolar lumen, atelectasis, and peribronchiolar, perivascular infiltrates of inflammatory cells (Fig. 2c). This was recorded in 75/144(52.08\%) lungs. Bronchiolitis was associated with widespread degeneration and necrosis of the epithelial cells (33/144, 22.92\%) (Fig. 3a). The main finding in the alveoli was presence of inflammatory cells consisting predominantly of neutrophils, macrophages, and plasma cells (Fig. 3b); this was recorded in 57/144 (39.58\%) of the lungs. A few lung sections showed hyperplasia of bronchial submucosal glands (Fig. 3c). Sections of nematode worm (Metastrongylus sp.) were found in the bronchial lumen of three of the lung samples (Fig. 4a). Acute verminous bronchitis with a section of nematode (Metastrongylus apri) was seen in the bronchial lumen (Fig. 4b), while several worm larvae sections admixed with mucus and intraluminal cellular exudate were observed (Fig. 4c).

\subsection{Immunohistochemical findings}

SIV (H1N1) antigen was detected in 7/204 (3.43\%) of the lungs samples. All positive cases showed a granular brown staining in the nuclei and cytoplasm of the bronchial and bronchiolar epithelial cells and bronchial submucosal glandular epithelial cells (Fig. 5) in the sections 

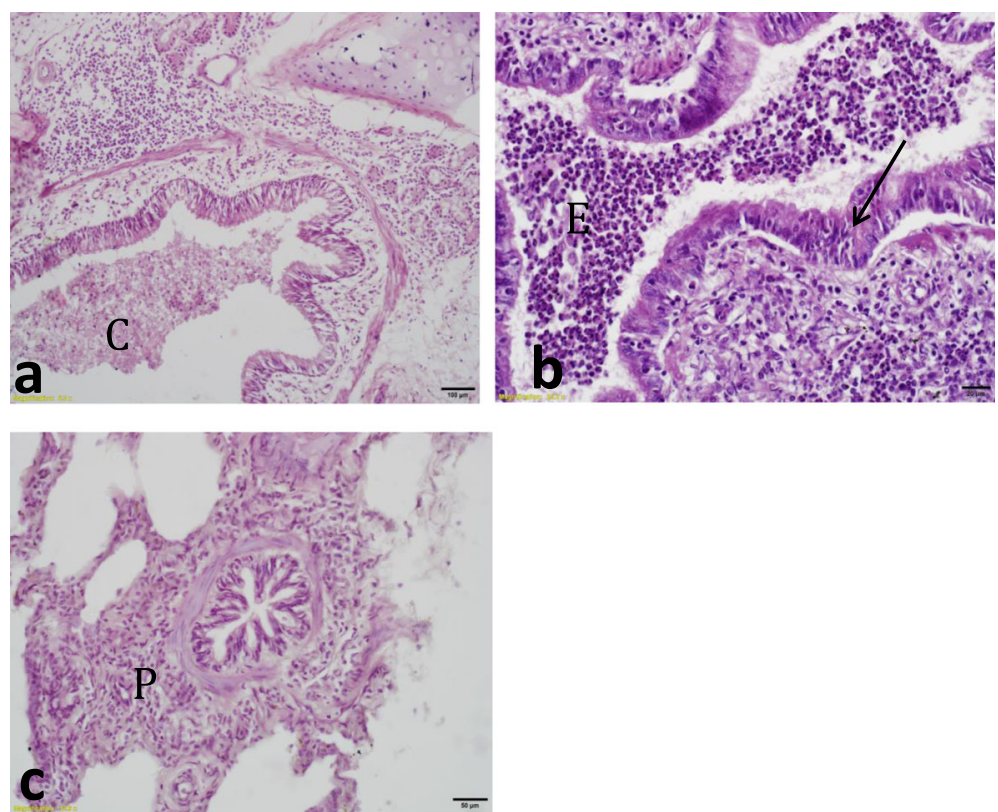

Fig. 2 Photomicrograph of lung sections showing a mild bronchitis and catarrhal exudate in the bronchial lumen (C). H\&E stain, Bar $=100 \mu$ m. $\mathbf{b}$ Suppurative bronchiolitis with concurrent epithelial hyperplasia (arrowed) and presence of intraluminal purulent exudate desquamated epithelia cells and necrotic debris (E), and $\mathbf{c}$ attenuation of bronchiolar lumen, atelectasis, and peribronchiolar infiltrates of inflammatory cells (P). H\&E stain, Bar $=20 \mu \mathrm{m}$

of the lungs tissues from the infected pigs. Less intense staining was detected in the cytoplasm of the bronchiolar epithelial cells (Fig. 5d, e).

\section{Discussion}

Swine influenza A viruses infections are endemic in pigproducing countries around the world $[16,57,66]$. Molecular and surveillance studies carried out by several workers in Nigeria indicated the presence of SIV H1N1 subtype $[3-7,44]$. The present investigation showed that natural infection with the influenza A (H1N1) virus may induced both gross and histopathological lung lesions similar to those described in natural infections with the this virus [57, 64]. In the present study, histopathology revealed suppurative bronchitis, bronchiolitis, and pneumonia with concurrent epithelial hyperplasia with or without widespread degeneration and necrosis of the infected epithelial cells and thickening of alveolar septa due to cellular infiltration consisting predominantly of neutrophils and lymphocytes with a few macrophages and plasma cells. The lumina of most airways were filled with exudate consisting of neutrophils, desquamated cells, and necrotic debris. The histopathological findings of the present study are consistent with SIV infection and similar to the results of the previous studies of experimental infections [34, 35, 38] and natural infections [37, 57, 64]. SIV has been reported to have a tropism for the respiratory system where it attaches to and replicates in epithelial cells of the upper respiratory tract [17].
Infection then spreads to bronchi and bronchioles resulting in loss of cilia, extrusion of mucus, exudation of neutrophils and macrophages, and necrosis and metaplasia of airway epithelium [17]. Previous studies have also shown that neutrophil infiltration was due to increased levels of certain pro-inflammatory cytokines such as tumor necrosis factor (TNF- $\alpha$ ), interferon (IFN$\alpha$ ), and interleukin-1 (IL-1 and interleukin-8 (IL-8)) during SIV infection $[36,39,67]$. This causes damage to the respiratory tract and reduces the ability to clear the infection and also decreases macrophage function $[23,55]$.

In the present study, there was hyperplasia of bronchial submucosal glands; this could indicate that the virus replicate in the submucosal glands resulting in the observed lesion. However, this observation has not been previously reported in SIV infection. In this study, three of the positive cases had section of lungworm in the bronchial lumen, resulting in verminous bronchitis with presence of Metastrongylus apri in the bronchial lumen and worm larvae admixed with mucus and intraluminal cellular exudate. Metastrongylosis may still present a major concern for outdoor pig herds in areas at high parasitic risk in Nigeria especially southwest where pigs have access to earthworm as in the case of indigenous free-range pigs. The possibility of SIV being transmitted by lungworms has earlier been reported [43].

The present result demonstrated that SIV antigens can be detected in formalin-fixed, paraffin-embedded tissue specimens of the pig using a monoclonal antibody. 

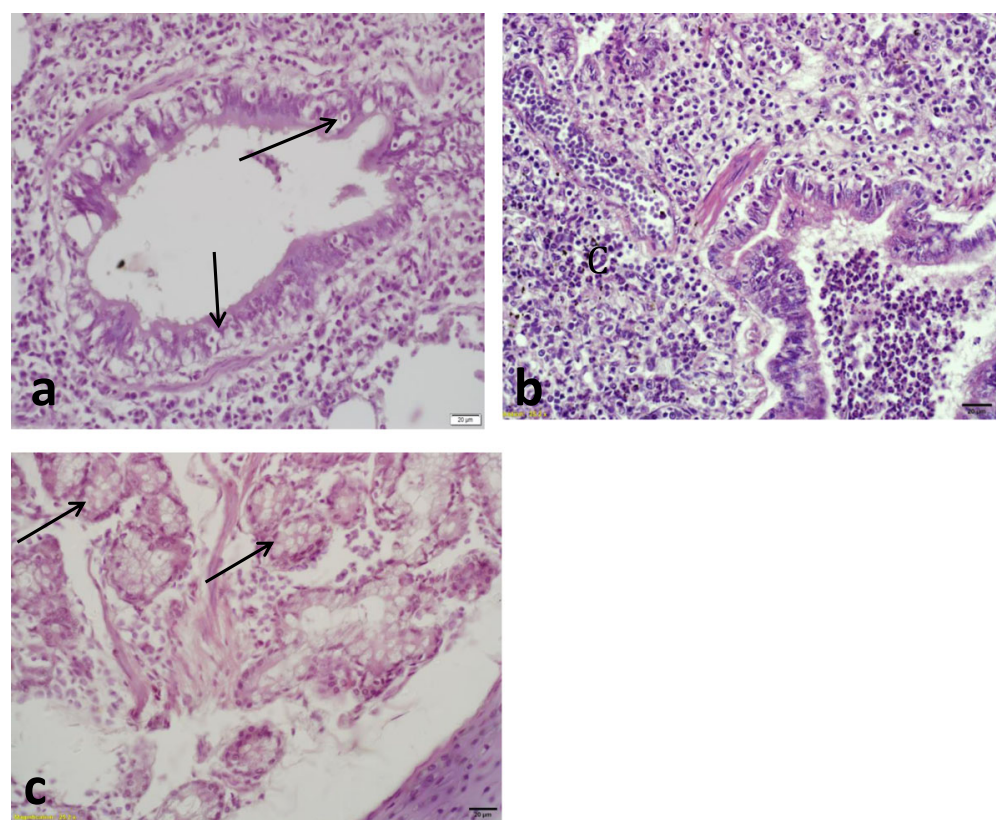

Fig. 3 Photomicrograph of lung sections showing a bronchiolitis with widespread degeneration and necrosis of the infected bronchiolar epithelial cells (arrowed), $\mathbf{b}$ marked thickening of the alveolar septa due to cellular infiltration (C) consisting predominantly of neutrophils and a few mononuclear cells, and c hyperplasia of bronchial submucosal glands (arrowed). H\&E stain, Bar $=20 \mu m$

Positive immunochemical staining for SIV was detected in the bronchial and bronchiolar epithelial cells, alveolar macrophages, and bronchial submucosal glands of pigs in this investigation. In situ hybridization and immunohistochemical results had suggested that the major site of infection of SIV was the bronchial and bronchiolar epithelial cells. Several studies have earlier reported that detection of viral antigens was primarily in the bronchial and bronchiolar epithelial cells as well as and alveolar macrophages [29, 35, 37, 63]. The immunohistochemical findings of the present study are consistent with the results of the previous studies in terms of distribution and
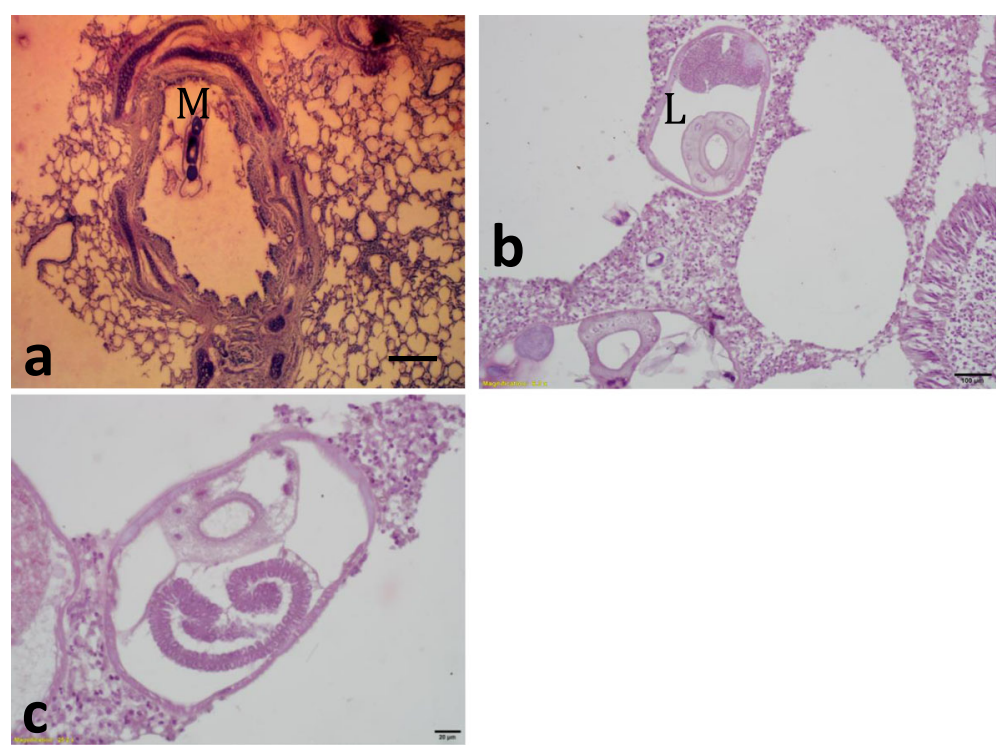

Fig. 4 Photomicrograph of lung sections showing a acute verminous bronchitis with a section of nematode (Metastrongy/us apri) (M) in the bronchial lumen, $\mathbf{b}$ worm larvae sections (L) admixed with mucus and intraluminal cellular exudate. H\&E stain, Bar $=100 \mu \mathrm{m}$. $\mathbf{c}$ Is a higher magnification of a larva showing cellular exudate mainly composed of eosinophils and a few neutrophils. H\&E stain, Bar $=10 \mu \mathrm{m}$ 


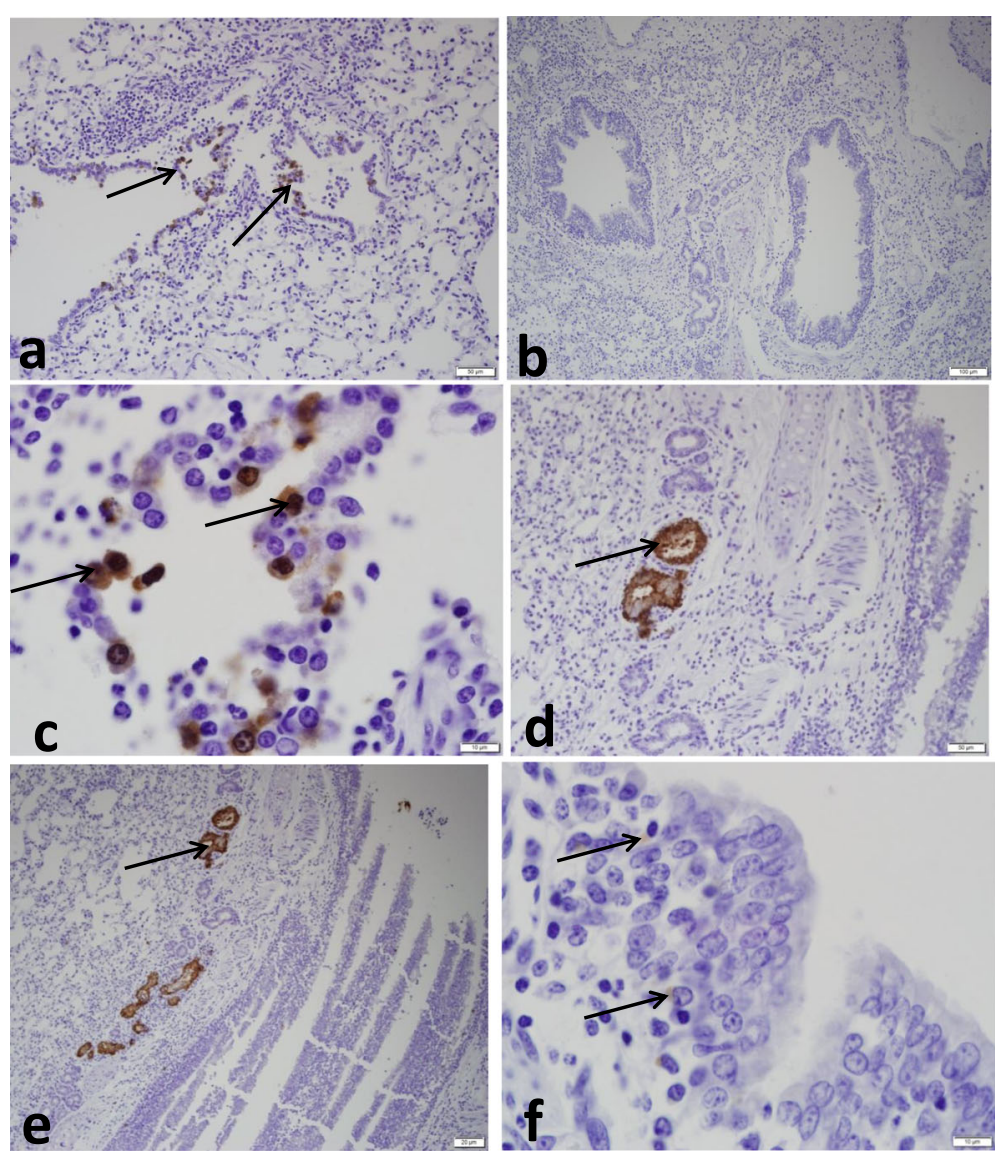

Fig. 5 Photomicrograph of lung sections of SIV-positive control showing a an intense granular brown immunohistochemical staining in the alveolar macrophages (arrowed), b negative control without immunohistochemical reaction. Streptavidin-peroxidase, DAB. Bar $=10 \mu \mathrm{m}, \mathbf{d}, \mathbf{e}$ intense immunosignal in the bronchial submucosal glandular epithelial cells (arrowed). Streptavidin-peroxidase, DAB. Bar $=10 \mu \mathrm{m}$, and $\mathbf{f}$ less intense immunosignal was detected in the nuclei and cytoplasm of the bronchiolar epithelial cells (arrows). Streptavidin-peroxidase, DAB. Bar $=50 \mu m$

localization of the viral antigens in the lungs $[35,37,42]$. However, in addition, viral antigens were detected in the bronchial submucosal glands. The histopathological changes observed in the bronchial submucosal glands and the detection of the viral antigens in this site could imply that the virus actually replicate within the epithelial cells of bronchial submucosal glands.

In situ hybridization and immunohistochemistry results had previously reported that SIV infects alveolar macrophages where immune-signals were detected $[35,37,42$, 63]. Destruction of alveolar macrophages by the virus is an indication of a direct pathogenic effect of SIV and such changes adversely affect the pulmonary host defense mechanisms and may lead to secondary viral and bacterial infections [36]. This accounts for the reason SIV is often seen in infection with combination of other viruses and bacterial pathogens including PRRSV, PRCV, Mycoplasma hyopneumoniae, Actinobacillus pleuropneumoniae, Haemophilus spp., and Pasteurella multocida that result in porcine respiratory disease complex [52]. A combination of any of these pathogens with SIV had been reported to often produce more pronounced and protracted respiratory disease and higher mortality than is seen in uncomplicated cases of SIV infection [42, 65].

The too low result indicated by IHC test could indicate low level of clinical form of the infection and that higher percentage of the cases are still at subclinical level; it is noteworthy that only subtype H1N1 was targeted and clinical form of the disease has not been reported in Nigeria before this time. The present study confirmed the presence SIV subtype H1N1 in pig herds in Nigeria and provides some insight into the pathogenesis of the infection and pathogenicity of the virus. Zoonotic infections of humans with swine influenza viruses have earlier been diagnosed and confirmed by isolation of swine influenza viruses from both pigs and their caretakers on farms in Nigeria $[2,6,10]$. Therefore, it is advised that people working on pig farms should maintain high level of biosafety and personal hygiene.

\section{Conclusion}

The detection of SIV (H1N1) antigens in the lung of the infected pigs indicate that natural respiratory disease may 
be induced by the virus and possibly in association with other bacterial and viral pathogens. It is therefore suggested that further studies should be done on the molecular epidemiology and characterization of the virus detected in this study to shed more light on the transmission and genetic diversity of the virus and to determine the prevalent of other SIV subtypes circulating in Nigerian pigs.

\section{Acknowledgments}

The authors would like to thank James Taiwo Apantaku, Idowu Ojugbele and Bisi Afuwape of the Department of Veterinary Pathology, Federal University of Agriculture, Abeokuta, Nigeria for their invaluable technical assistance in preparation of the slides and Mrs O.O. Ogunsanya for secretarial assistance.

\section{Authors' contributions \\ MOO developed the study concept and designed experiments, and major contributor in writing of the manuscript. MOO and AAA wrote the draft of the manuscript. MOO and OLA performed immunohistochemistry and interpreted the immunohistochemistry data. OOA and SOA performed the histological examination of the lung. All authors contributed to discussion and reviewed the manuscript. All authors read and approved the final. manuscript.}

\section{Funding}

This research did not receive any specific grant from funding agencies in the public, commercial, or not-for-profit sectors.

\section{Availability of data and materials}

Not applicable.

\section{Ethics approval and consent to participate}

Not applicable.

\section{Consent for publication}

Not applicable.

\section{Competing interests}

The authors declare that they have no competing interests.

\section{Author details}

'Department of Veterinary Pathology, College of Veterinary Medicine, Federal University of Agriculture, Abeokuta, Nigeria. ${ }^{2}$ Department of Veterinary Pathology, Faculty of Veterinary Medicine, University of Ibadan, Ibadan, Nigeria.

Received: 6 September 2019 Accepted: 30 January 2020

Published online: 06 May 2020

\section{References}

1. Adebambo AO (1982) Evaluation of the genetic potential of the Nigerian indigenous pigs. In: Proceedings Second World Conference Genetic Application, Madrid, Spain, pp 133-138

2. Adeola OA, Olugasa BO, Emikpe BO, Folitse RD (2019) Syndromic survey and molecular analysis of influenza viruses at the human-swine interface in two West African cosmopolitan cities suggest the possibility of bidirectional interspecies transmission. Zoonoses Public Health 66(2):232-247. https://doi. org/10.1111/zph.12559

3. Adeola OA, Olugasa BO, Emikpe BO (2016) Antigenic detection of human strain of influenza virus $A$ (H3N2) in Swine populations at three locations in Nigeria and Ghana during the dry early months of 2014. Zoonoses Public Health 63(2):106-11. https://doi.org/10.1111/zph.12210

4. Adeola OA, Olugasa BO, Emikpe BO (2015) Detection of pandemic strain of influenza virus (A/H1N1/pdm09) in pigs, West Africa: implications and considerations for prevention of future influenza pandemics at the source. Infec Ecol Epidemiol 5:30227. https://doi.org/10.3402/iee.v5.30227

5. Adeola OA, Adeniji JA, Olugasa BO (2010) Detection of haemagglutination inhibiting antibodies against human $\mathrm{H} 1$ and $\mathrm{H} 3$ strains of influenza $\mathrm{A}$ viruses in pigs in Ibadan. Nigeria Zoonoses Public Health 57:e89-e94. https://doi.org/10.1111/j.1863-2378.2009.01268.x

6. Adeola OA, Adeniji JA (2010) Prevalence of antibodies to influenza viruses among handlers of live pigs at three locations in Ibadan, Nigeria. Vet Ital 46(2):147-153

7. Adeola OA, Adeniji JA, Olugasa BO (2009) Isolation of influenza A viruses from pigs in Ibadan, Nigeria. Vet Ital 45:383-390

8. Adetunji MO, Adeyemo KE (2012) Economic efficiency of pig production in Oyo State, Nigeria: a stochastic production frontier approach. Am J Exp Agriculture 2(3):382-394

9. Antia RE, Akpavie SO, Ikede BO (1981) Observations on the pathology of pig pneumonias in Ibadan, Nigeria. Bulletin Animal Health Production in Africa 29:309-316

10. Awosanya EJ, Ogundipe G, Babalobi O, Omilabu S (2013) Prevalence and correlates of influenza-A in piggery workers and pigs in two communities in Lagos, Nigeria. Pan African Medical Journal 16:102. https://doi.org/10.11604/ pamj.2013.16.102.1450

11. Babalobi OO, Olugasa BO, Oluwayelu DO, ljagbone IF, Ayoade GO, Agbede SA (2007) Analysis and evaluation of mortality losses of the 2001 African swine fever outbreak, Ibadan, Nigeria. Tropical Animal Health and production 39(7):533-542

12. Bancroft JD, Gamble M (2014) Theory and practice of histological techniques, Sixth edn. Elsevier Pub, pp 10-15

13. Bikour MH, Cornaglia E, Weber JM, Elazhary Y (1994) Antigenic characterization of an H3N2 swine influenza virus isolated from pigs with proliferative and necrotizing pneumonia in Quebec. Can. J. Vet. Res. 58:287-290

14. Bochev I (2007) Porcine respiratory disease complex (PRDC): A review. I. Etiology, epidemiology, clinical forms and patho-anatomical features. Bulgarian J Veterinary Med 10(3):131-146

15. Brockmeier SL, Halbur PG, Thacker EL (2002) Porcine respiratory disease complex. In: Brogden K, Guthmiller JM (eds) Polymicrobial diseases. Chapter 13. American Society for Microbiology Press, Washington DC

16. Brown $\mathbb{H}(2000)$ The epidemiology and evolution of influenza viruses in pigs. Veterinary Microbiology 74(1-2):29-46

17. Brown IH, Chakraverty P, Harris PA, Alexander DJ (1995) Disease outbreaks in pigs in Great Britain due to an influenza A virus of H1N2 subtype. Vet Rec 136:328-329

18. Caswell JF, William KT (2016) Respiratory System. In: Maxie G (ed) Jubb, Kennedy and Palmer pathology of domestic animals, Volume 2, 6th edn. Elseveir, Inc, St Loius Missouri

19. Ceribasi AO, Ceribasi S, Ozkaraca M (2016) Immunohistochemical detection of Bovine herpesvirus type 1 and Bovine adenovirus type 3 antigens in frozen and paraffinized lung sections of pneumonic sheep and goats. Veterinarski Archiv 86(1):9-21

20. Choi C, Ha SK, Chae C (2004) Detection and isolation of H1N1 influenza virus from pigs in Korea. Vet Rec 154:274-275

21. Choi YK, Goyal SM, Joo HS (2003) Retrospective analysis of etiologic agents associated with respiratory diseases in pigs. Canadian Veterinary Journal 44:735-737

22. Dalhatu IT, Medina-Marino A, Olsen SJ, Hwang I, Gubio AB, Ekanem EE, Coker EB, Akpan H, Adedeji AA (2012) Influenza viruses in Nigeria, 20092010: results from the first 17 months of a national influenza sentinel surveillance system. J Infec Dis 206(Suppl.1):S121-S128

23. Dea S, Bilodeau R, Sauvageau R, Montpetit C, Martineau GP (1992) Antigenic variant of swine influenza virus causing proliferative and necrotizing pneumonia in pigs. J Vet Diagn Invest 4:380-392

24. Deng YM, lannello YM, Smith I, Watson J, Barr IG, Daniels P, Komadina N, Harrower B, Wong FYK (2012) Transmission of influenza A (H1N1) 2009 pandemic viruses in Australian swine. Influenza and Other Respiratory Viruses 2012(6):e42-e47. https://doi.org/10.1111/j.1750-26592.0120.0337.x

25. Ducatez MF, Awoume F, Webby RJ (2015) Influenza A (H1N1) pdm09 virus in pigs, Togo, 2013. Veterinary Microbiol 177:201-205. https://doi.org/10. 1016/j.vetmic. 2015.020.28

26. Easterday BC, Van Reeth K (1992) Swine influenza. In: Straw BE, D'Allaire S, Mengeling WL, Taylor DJ (eds) Disease of Swine, 8th edn. lowa State University Press, Ames, lowa

27. Emikpe BO, Jarilre TA, Adediran OA, Olaniyi MO, Dikeogu TC (2018) Haematology, brochoalveolar cellular changes and pathology of swine pneumonia in Nigeria. Sokoto Journal of Veterinary Sciences 16(2):1-9. https://doi.org/10.4314/sokjvs.v16i2.1

28. Gray GC, McCarthy T, Capuano AW (2007) Swine workers and swine influenza virus infections. Emerging Infectious Diseases 13(12):1871-1878 
29. Haines DM, Edwin WEH, Clark EG (1993) Immunohistochemical detection of swine influenza A virus in formalin-fixed and paraffin-embedded tissues. Can J Vet Res 57:33-36

30. Hansen MS, Pors SE, Jensen HE, Bille-Hansen V, Bisguard M, Flachs EM, Nielsen OL (2010) An investigation of the Pathology and Pathogens associated with Porcine Respiratory Disease Complex in Denmark. J Comp Path 143:120-131. https://doi.org/10.1016/j.jcpa.2010.01.012

31. Hiromoto Y, Parchariyanonc S, Ketusing N, Netrabukkana P, Hayashia T, Kobayashia T, Takemaea N, Saitoa T (2012) Isolation of the pandemic (H1N1) 2009 virus and its reassortant with an H3N2 swine influenza virus from healthy weaning pigs in Thailand in 2011. Virus Research 169:175-181

32. Holyoake PK, Kirkland PD, Davis RJ, Arzey KE, Watson J, Lunt RA, Wang J, Wong F, Moloney BJ, Dunn SE (2011) The first identified case of pandemic H1N1 influenza in pigs in Australia. Australian Veterinary Journal 89:427-431. https://doi.org/10.1111/j.1751-08132.0110.0844.x

33. Ito T, Couceiro JNS, Kelm S, Baum LG, Krauss S, Castrucci MR, Donatelli I, Kida H, Paulson JC, Webster RG, Kawaoka Y (1998) Molecular basis for the generation in pigs of influenza A viruses with pandemic potential. J Virol 72: 7367-7373

34. Janke BH (2013) Clinicopathological features of swine influenza. Curr Top Microbiol Immunol 370:69-83

35. Janke BH (2014) Influenza A virus infection in Swine: pathogenesis and diagnosis. Veterinary Pathol 51(2):410-426. https://doi.org/10.1177/ 0300985813513043

36. Jo SK, Kim HS, Cho SW, Seo SH (2007) Pathogenesis and inflammatory responses of swine H1N2 influenza viruses in pigs. Virus Res 129(1):64-70. https://doi.org/10.1016/j.virusres.2007.05.005

37. Jung T, Choi C, Chae C (2002) Localization of swine influenza virus in naturaly infected pigs. Vet Pathol 39:10-16. https://doi.org/10.1354/vp. 39-1-10

38. Jung $\mathrm{K}, \mathrm{Ha}$ Y, Chae C (2005) Pathogenesis of swine influenza virus subtype H1N2 infection in pigs. J Comp Pathol 132(2-3):179-184. https://doi.org/10. 1016/j.jcpa.2004.09.008

39. Karasin Al, Olsen CW, Brown IH, Carman S, Stalker M, Josephson G (2000) H4N6 influenza virus isolated from pigs in Ontario. Canadian Veterinary J 41: 938-939

40. Karasin Al, West K, Carman S (2004) Characterization of avian H3N3 and H1N1 influenza A viruses isolated from pigs in Canada. J Clin Microbiol 42(9):4349-4354

41. Kong W, Ye J, Guan S, Liu J, Pu J (2014) Epidemic status of swine influenza virus in China. Indian J Microbiol 54(1):3-11. https://doi.org/10.1007/s12088013-0419-7

42. Larochelle R, Sauvageau R, Magar R (1994) Immunohistochemical detection of swine influenza virus and porcine reproductive and respiratory syndrome virus in porcine proliferative and necrotizing pneumonia cases from Quebec. Can Vet J 35:513-515

43. Lopez A (2012) Respiratory system, mediastinum, and pleurae. In: Pathologic Basis of Veterinary Disease MaGavin MD, Zachary JF (ed). Chapter 9. (5 $5^{\text {th }}$ edition). Mosby Elsevier Publ. pp 514-519.

44. Meseko C, Odaibo G, Olaleye C (2014) Detection and isolation of 2009 pandemic influenza A/H1N1 virus in commercial piggery, Lagos, Nigeria. Vet Microbiol 168:197-201

45. Nelson Ml, Stratton J, Killian ML, Janas-Martindale A, Amy L, Vincent AL (2015) Continual reintroduction of human pandemic H1N1 influenza A viruses into swine in the United States, 2009 to 2014. J Virol 89:6218-6226

46. Njabo KY, Fuller TL, Chasar A, Pollinger JP, Cattoli P, Terregino C, Monne I, Reynes JM, Njouom R, Smith TB (2012) Pandemic AVHINI/2009 influenza virus in swine, Cameroon, 2010. Vet Microbiol 156(1-2):189-192

47. Odemuyiwa SO, Adebayo IA, Ammerlaan W, Ajuwape ATP, Alaka OO, Oyedele Ol, Soyelu KO, Olaleye DO, Otesile EB, Muller CP (2000) An outbreak of African swine fever in Nigeria: Virus isolation and molecular characterization of the VP72 Gene of a first isolate from West Africa. Virus Gene 20(2):139-142

48. Olaleye OD, Omilabu SA, Baba SA, Fagbami AH (1990) Haemaglutinationinhibition (HI) Antibodies against strains of influenza a virus in Horses and Pigs Sera in Nigeria. J Hyg Epidemiol Microbial Immunol 34(4):365-370

49. Olaniyi MO (2017) Pathology and pathogens associated with swine pneumonias in southwest Nigeria. Federal University of Agriculture, Abeokuta, Nigeria, Ph.D dissetation

50. Olsen CW (2002) The emergence of novel swine influenza viruses in North America. Virus Research 182:199-210
51. Olsen CW, Brammer L, Easterday BC (2002) Serologic evidence of H1 swine Influenza virus infection in swine farm residents and employees. Emerging Infectious Diseases 8(8):814-819

52. Opriessnig T, Gimenez-Lirola LG, Halbur PG (2011) Polymicrobial respiratory disease in pigs. Animal Health Research Reviews 12(2):133-148. https://doi. org/10.1017/S146625231000120

53. Otesile EB, Ajuwape ATP, Odemuyiwa SO, Akpakvie S, Olaifa AK, Odaibo GO, Olaleye OD, Adetosoye Al (2005) Field and experimental investigation of an outbreak of African Swine fever in Nigeria. Revue d' Elev de Medecines Pays Tropicaux 58(1-2):1-26

54. Reid AH, Fanning TG, Hultin JV, Taubenberger JK (1999) Origin and evolution of the 1918 'Spanish' influenza virus haemagglutinin gene. Proceedings of the National Academy of Sciences of the United States of America 96:1651-1656

55. Rekik MR, Arora DJ, Dea S (1994) Genetic variation in swine influenza virus A isolate associated with proliferative and necrotizing pneumonia in pigs. J Clin Microbiol 32:515-518

56. Saka JO, Adesehinwa AOK, Ajala MK (2010) Incidence of African swine fever (ASF) and associated implication on pig production in Lagos State, Nigeria. Bulgarian Journal of Agric Science 16(1):80-90

57. Schaefer R, Zanella JRC, Brentano L, Vincent AL, Ritterbusch GA, Silveira $S$, Caron L, Mores N (2011) Isolation and characterization of a pandemic H1N1 influenza virus in pigs in Brazil. Pesquisa Veterinária Brasileira 31(9):761-767

58. Shima FK, Garba HS (2014) Prevalence of characteristic macroscopic lung pathologies in pigs at slaughter in Makurdi, Benue State, Nigeria. Bulletin of Animal Health Production in Africa 62:377-385

59. Snoeck CI, Abiola OJ, Sausy A, Okwen MP, Ayoade GO, Ademola A, Owoade AA, Claude P, Muller CP (2015) Serological evidence of pandemic (H1N1) 2009 virus in pigs, West and Central Africa. Veterinary Microbiology 176(1-2): 165-171 https://doi.org/10.1016/j.vetmic.2014.12.022

60. Stark KDC (2000) Epidemiological investigation of the influence of environmental risk factors on respiratory diseases in swine: A literature review. Vet. Journal 159:37-56

61. Straw BE (1991) Performance measured in pigs with pneumonia and housed in different environments. J Am Vet Med Assoc 198:627-630

62. Thacker EL (2001) Porcine respiratory disease complex- what is it and why does it remain a problem. Pig J 48:66-70

63. Vincent LL, Janke BH, Paul PS, Halbur PG (1997) A monoclonal-antibody-based immunohistochemical method for the detection of swine influenza virus in formalin-fixed, paraffin-embedded tissues. J Vet Diagn Invest 9:191-195

64. Valheim M, Gamlem H, Gjerset B, Germundsson A, Lium B (2011) Pathological findings and distribution of pandemic influenza A (H1N1) 2009 virus in lungs from naturally infected fattening pigs in Norway. Influenza Research and Treatment. https://doi.org/10.1155/2011/565787

65. Van Reeth K, Brown IH, Olsen CW (2012) Influenza virus. In: Zimmerman JJ, Ramirez A, Schwartz KJ, Stevenson GW (eds) Diseases of swine, 10th edn. Wiley-Blackwell, Ames

66. Van Reeth $\mathrm{K}$, Brown $\mathrm{IH}$, Durrwald $\mathrm{R}$, Foni $\mathrm{E}$, Labarque $\mathrm{G}$, Lenihan $\mathrm{P}$, Maldonado J, Markowska-Daniel I, Pensaert M, Pospoisil Z, Koch G (2008) Seroprevalence of H1N1, H3N2 and H1N2 influenza viruses in pigs in seven European countries in 2002-2003. Influenza and other Respiratory Viruses 2(3):99-105. https://doi.org/10.1111/j.1750-2659.2008.00043.x

67. Van Reeth K, Nauwynck H (2000) Proinflammatory cytokines and viral respiratory disease in pigs. Veterinary Research 31:187-213

68. Zhou NN, Senne DA, Landgraf JS, Swenson SL, Erickson G, Rossow K, Liu L, Yoon K, Krauss S, Webster RG (2000) Emergence of H3N2 reassortant infuenza A viruses in North American pigs. Veterinary Microbiology 74:47-58

\section{Publisher's Note}

Springer Nature remains neutral with regard to jurisdictional claims in published maps and institutional affiliations. 